\title{
A OCUPAÇÃO DAS TERRAS NA COMUNIDADE CÓRREGO DAS PEDRAS NO SUDOESTE MATO-GROSSENSE
}

\author{
José Pereira Filho ${ }^{1}$
}

\section{Resumo}

O presente artigo é resultado de uma pesquisa de doutoramento em andamento, intitulada: "Ruralidade: um estudo a partir da vida material e imaterial da comunidade Córrego das Pedras". O objetivo é analisar a dinâmica social referente às formas de sobrevivência das famílias que vivem em minis e pequenas propriedades denominadas sítios, na comunidade rural Córrego das Pedras. O campo empírico é um espaço de terras férteis, ocupadas no início da década de 60 , onde residem e trabalham os sujeitos de pesquisa. A metodologia é qualitativa, tendo a história oral como recurso metodológico, sendo a observação direta e as entrevistas semiestruturadas os principais instrumentos de geração de dados. Para a presente reflexão, analisar-se-á o processo de ocupação das terras do Município de Tangará da Serra, enfocando a ocupação das terras da comunidade em questão, no contexto de colonização do Estado de Mato Grosso.

Palavras-chave: Migração. Ocupação. Córrego das Pedras.

1 José Pereira Filho é mestre em educação e doutor pelo Programa de Pós-Graduação da Universidade Federal de São Carlos (UFSCAR), DINTER UFSCAR/UNEMAT, em convênio com a Coordenação de Aperfeiçoamento de Pessoal de Nível Superior (CAPES), desenvolvendo pesquisa na comunidade Córrego das Pedras, Município de Tangará da Serra, Estado de Mato Grosso, Brasil, sob orientação da Professora Dra. Maria Aparecida de Moraes Silva do Programa de Pós Graduação em Sociologia da UFSCAR. Contatos: e-mail: zepereiraunemat@gmail.com - Fone: 55(65)999970613. 


\section{Abstract}

This article is the result of a doctoral research entitled: "Rurality: a study from material and immaterial life of Córrego das Pedras community." The aim is to analyze the social dynamics concerning ways of families' survival which live in mini and small properties called croft in Córrego das Pedras rural community. The empirical field is a space of fertile land occupied in the early 60's, where the research subjects have been living and working. The research methodology is qualitative, taking oral reports as a methodological resource, with direct observation and semi-structured interviews being the main instruments of data generation. For this reflection, it will be analyzed the process of land settlement in Tangará da Serra, focusing on the occupation of the community lands in question in the context of the colonization process of Mato Grosso state.

Key Words: Migration. Occupation. Córrego das Pedras.

\section{Introdução}

O processo de colonização do Município de Tangará da Serra - onde localiza-se a comunidade estudada -, situado no sudoeste do Estado de Mato Grosso, iniciou-se no final da década de 1950. Uma de suas características principais foi a existência de minis, pequenas e médias propriedades rurais, denominadas sítios, com a consequente formação de inúmeras comunidades rurais. Ainda hoje, existe significativo remanescente dessas comunidades rurais.

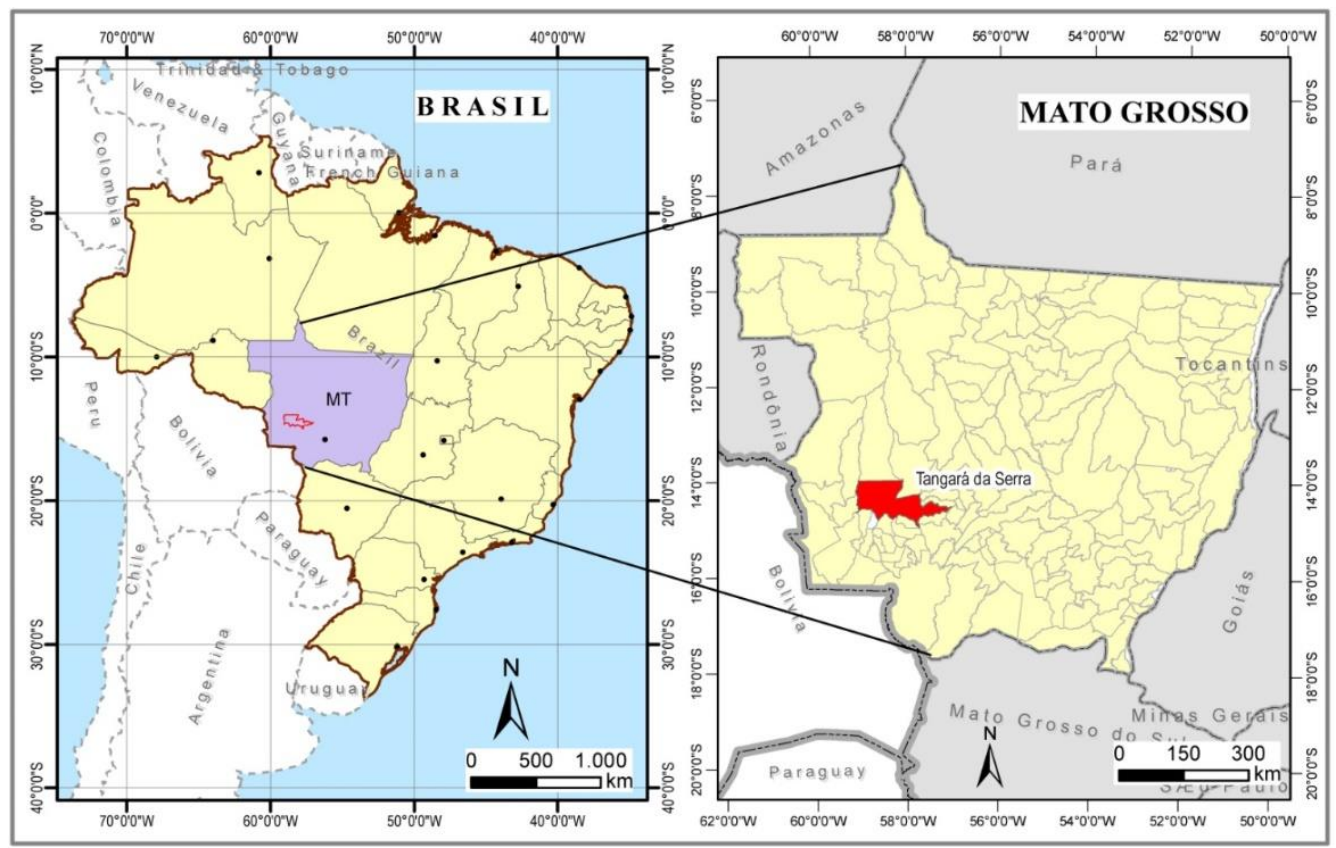

Fonte: Por Almir José Azevedo, a partir de Cartas Topográficas IBGE/DSG, Imagens de Satélites, dados Disponibilizados pela SEMA/MTSEMA/MT. 


\section{Figura 01 - Mapa identificador do município de Tangará da Serra/MT}

Conforme fontes do Instituto Brasileiro de Geografia e Estatística (IBGE), o Município de Tangará da Serra localiza-se no bioma Cerrado e Amazônia, com área de 11.323,685 km², com população estimada de 96.932 habitantes para o ano de 2016, sendo 52,2020\% do território, correspondente a 5.911,185 km², formado por reservas indígenas da "Etnia Paresí"2, devidamente demarcadas.

As comunidades rurais são espaço de referência da vida coletiva das famílias do campo, preservando ainda hoje, em parte, tais características. A colonização se deu principalmente por meio da ocupação de áreas rurais voltadas às atividades agrícolas, com base na mão-de-obra familiar, pois eram as famílias que migravam e ocupavam as terras, onde desenvolviam, em um primeiro momento, a agricultura de subsistência.

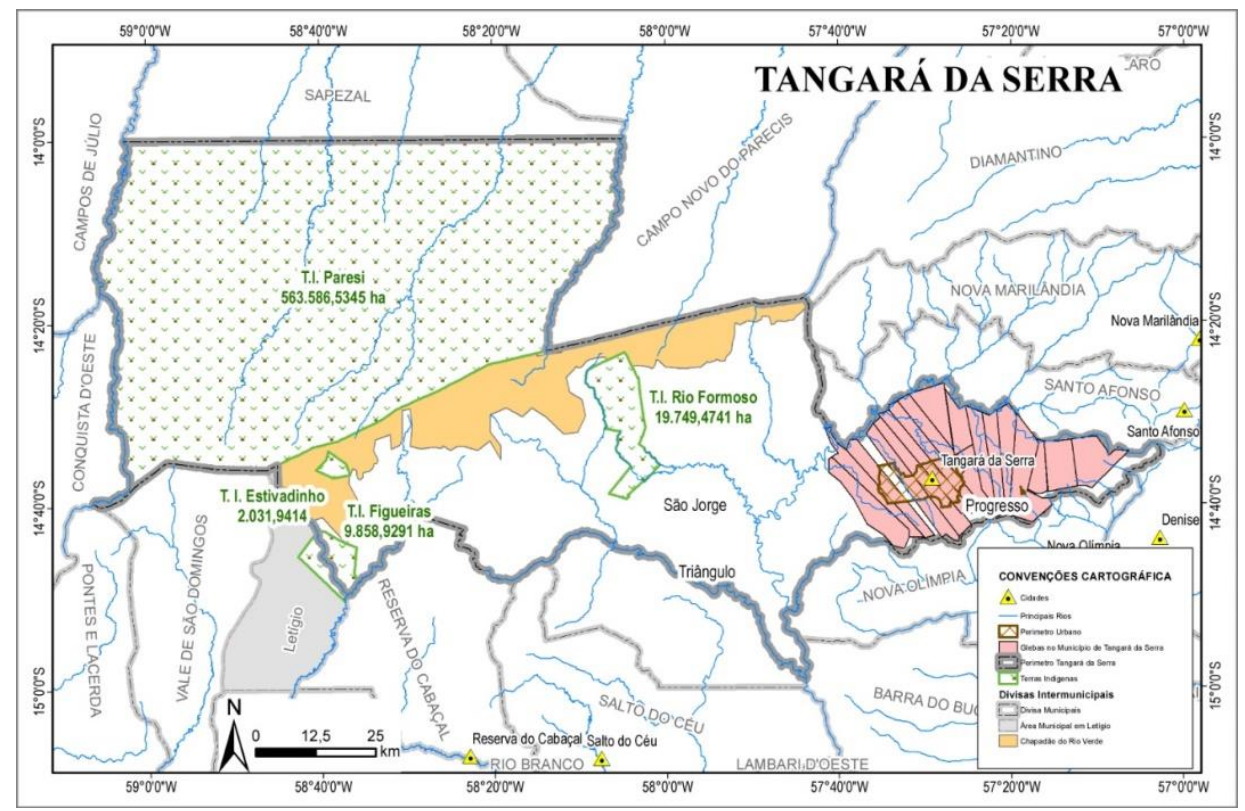

Fonte: Por: Almir José Azevedo, desenhista técnico cartográfico. Cartas Topográficas IBGE/DSG, Imagens de Satélites, dados do INTERMAT.

2 Paresí ou Parecis - Nome dado pelos brancos para identificar a Etnia "Haliti", que significa povo. O território das terras indígenas da Etnia Haliti ou Paresí é distribuído em quatro polígonos distintos, estando um polígono localizado nas confrontações com o Município de Barra do Bugres e parte do polígono localizado no Município de Tangará da Serra e parte no Município de Barra do Bugres. 


\section{Figura 02 - Mapa do Município de Tangará da Serra ${ }^{3}$}

A Comunidade Córrego das Pedras, situada a $12 \mathrm{~km}$ do eixo central da cidade, constituise como uma das primeiras ocupações rurais, iniciada no ano de 1964, quando para lá migrou um grupo de mineiros, paulistas e paranaenses, em busca de melhores condições de vida. Tratase de um locus que preserva parte da população remanescente do processo migratório inicial e que, ao longo do tempo, produziu relações de vida material ${ }^{4}$ com variada produção agrícola, pecuária leiteira e de corte e hortifrutigranjeiros e imaterial ${ }^{5}$ tendo como referência a tradicional festa de São Sebastião ${ }^{6}$, sacra e profana, com culinária advinda da tradição mineira e paulista.

O quadro abaixo demonstra o número expressivo de minis, pequenas e médias propriedades ocupando um espaço menor de terras, inversamente, um quantitativo menor de grandes produtores, ocupando uma fração muito maior das terras com predomínio das grandes propriedades rurais, caracterizadas como fazendas do agronegócio ${ }^{7}$.

3 Para fins de melhor identificação das informações constantes do mapa, prestamos as seguintes informações: os polígonos identificados em cor verde são terras indígenas, pertencentes aos povos Paresí, sendo a maior porção, a do Chapadão do Parecis e as menores porções, no Baixo Parecis; o polígono amarelo são extensões de terras de propriedades particulares no Alto Parecis, que constituem fazendas do agronegócio no Município de Tangará da Serra na região identificada como Chapadão do Rio Verde; o polígono em cor rosa constitui o primeiro projeto de ocupação da região de Tangará da Serra, terras cortadas em glebas entre a Serra do Tapirapuã e o Rio Sepotuba, perceptíveis em polígonos menores dentro do polígono maior. No polígono maior está identificada a localização da Cidade de Tangará da Serra.

$4 \quad$ Vida material: constituída pela força de trabalho desprendida por homens e mulheres, em condições sociais determinadas que, compreende a construção dos meios de sobrevivência, composto essencialmente pelos bens materiais, como alimentação, moradia, deslocamento, roupas, remédios e outros, necessários à sobrevivência humana.

$5 \quad$ Vida imaterial: conjunto das experiências de vida, hábitos, costumes e tradições que, no seu conjunto, identificamos como cultura, presentes no contexto das relações sociais dos sitiantes da comunidade Córrego das Pedras, espaço de produção da vida material.

6 A festa de São Sebastião é tradicional, porque se repete, não sendo um acontecimento distinto, constituindo-se em um momento de celebração da comunidade, dos que lá vivem, dos que foram e voltam e da população citadina que mantém relações com a comunidade, tendo duas dimensões: a) religiosa, celebrada no dia 20 de janeiro, dia de São Sebastião, padroeiro e protetor dos sitiantes, para agradecer as graças recebidas no ano anterior e pedir as bênçãos para o ano em curso; b) social, realizada no mês de setembro, expressando o momento de celebração social. O cardápio é caipira, da roça, uma manifestação cultural que veio com as famílias migrantes, tendo como base a carne de porco frita e conservada na lata, frango caipira frito ao molho e com quiabo, tutu de feijão à moda mineira, torresmo ou pururuca, farofa de torresmo, arroz, couve refogada, angu, mandioca e salada (tomate com alface), músicas e danças caipiras.

$7 \quad$ O agronegócio brasileiro qualifica-se pela concentração de extensas áreas de terras, com plantação uniforme de produtos agrícolas, como soja, milho, algodão e cria, recria e engorda de gado, utilizando de modernas tecnologias. Para a safra 2018/19, Mato Grosso deverá ter 9,58 milhões de hectares de soja plantada, com previsão de colheita de 32,45 milhões de toneladas, quase $27 \%$ da produção nacional, o que coloca o Estado como o primeiro produtor do país. (Fonte: Instituto Mato-Grossense de Economia Agropecuária - Imea). Em relação ao rebanho bovino, Mato Grosso tem o maior rebanho brasileiro, com 27,9 milhões de animais, correspondente a 13,8\% da produção nacional. (Fonte: IBGE). Já o Município de Tangará da Serra possui 90.769 hectares de lavouras implantadas com previsão de colheita de 246.123 toneladas e um rebanho bovino com 208.373 reses, alojadas em uma área de 123.656 hectares. (Fonte: IBGE). 
Quadro 01 - Unidades rurais em relação ao tamanho, dimensionado em hectares (ha) no município de Tangará da Serra

\begin{tabular}{|l|r|r|}
\hline \multicolumn{1}{|c|}{ Tamanho de áreas em hectares - ha } & \multicolumn{1}{|c|}{$\begin{array}{c}\text { Área dos estabelecimentos em } \\
\text { hectares }\end{array}$} \\
\hline Até 10 há & 284 & 1.061 \\
\hline De 10 a menos de 20 há & 139 & 1.916 \\
\hline De 20 a menos de 50 há & 721 & 24.120 \\
\hline De 50 a menos de 100 há & 104 & 7.009 \\
\hline De 100 a menos de 200 há & 63 & 8.361 \\
\hline De 200 a menos de 500 há & 61 & 19.496 \\
\hline De 500 a menos de 1000 há & 46 & 33.011 \\
\hline De 1000 a menos de 2500 há & 34 & 53.525 \\
\hline De 2500 ha e mais & 30 & 241.103 \\
\hline Produtor sem área & 2 & 00 \\
\hline Total & 1.484 & 389.602 \\
\hline
\end{tabular}

Fonte: IBGE, 2010.

Nesse contexto, a presente reflexão propõe demonstrar como e em que cenário se deu a colonização da região da comunidade Córrego das Pedras, no Município de Tangará da Serra, no contexto da colonização e desenvolvimento do Estado do Mato Grosso.

\section{A ocupação das terras do Sudoeste de Mato-Grosso no contexto da colonização matogrossense}

A história da luta pelo acesso à terra e pela permanência nela não é recente. É fruto do processo de colonização do território brasileiro, que teve por base a concentração de enormes áreas de terras nas mãos das elites rurais e políticas, processo que se estendeu quando da abertura das fronteiras de exploração econômica nos diversos ciclos, da cana de açúcar à moderna monocultura da soja e criação do boi que hoje experienciamos. Para Moreira (2007, p.86):

No caso brasileiro, o domínio privado sobre o território nacional foi fundado no monopólio monárquico colonial do Reino Português nas concessões de uso das capitanias hereditárias e das sesmarias. Ainda sobre o poder monárquico do Império Brasileiro, a Lei de Terras, de 1850, reconhece a base da estrutura 
de uso anterior da terra com direitos de propriedade e institui os futuros acessos pela compra e venda no mercado de terras. Nos processos de urbanização e de industrialização do pós 1930 e no surto de democratização do pós 1946 essa forma de acesso à terra é tensionada pelo movimento camponês. O Estatuto da Terra, de 1964, instituído pelo poder do Golpe Militar do mesmo ano, não foi capaz de estabelecer parâmetros para uma significativa reforma do domínio privado sobre o território. O domínio do território não é democratizado. No presente, os elevados índices de concentração da propriedade da terra demonstram que a grande propriedade agrária ainda exerce um domínio quase absoluto sobre o território nacional. $\mathrm{Na}$ medida em que o Estado nacional moderno tem seu fundamento no domínio de um dado território e no direito burguês da propriedade privada, o Estado brasileiro ainda tem fortes raízes agrárias.

A ocupação do Estado de Mato Grosso desenvolveu-se com base nas políticas de ocupação do território brasileiro, nos séculos XVIII, XIX e XX, como parte das determinações econômicas orientadas pela Coroa Portuguesa e, após a Proclamação da República, pelas estratégias de ocupação pautadas pelo governo federal brasileiro.

No caso de Mato Grosso, o exercício do poder político foi utilizado como instrumento de legitimação de um modelo colonizador concentrador de terras em favor das elites rurais e seus apaniguados. "O poder dessas elites, representado historicamente pelo domínio das oligarquias, está imbricado no poder político que sempre esteve sob o comando dessa mesma classe dominante ou frações dessa classe". (MORENO, 2007, p. 33).

O início do processo de colonização do Estado de Mato Grosso compatibiliza-se com o processo de exploração mineral iniciada no início do século XVIII, primeiramente com o ouro e posteriormente com o diamante, abundantes em vários Estados brasileiros, incluindo Mato Grosso. Essa atividade tinha capacidade mobilizadora de pessoas para os chamados garimpos, locais de exploração, em função da sedução pela riqueza rápida e, ainda, por possibilitar a exploração manual, exigindo poucos investimentos.

Sobre o impacto populacional nas áreas de exploração garimpeira, Guimarães Neto (2006, p. 42) faz uma abordagem, com base em uma analogia com as ocupações no faroeste norte-americano. 
Em termos de ocupação ininterrupta, apesar da fragmentação, da fluidez e das rápidas mudanças de um lugar para outro, os deslocamentos acentuam-se, a partir da década de 1920. Nas descrições ufanistas chega-se a configurar o movimento para os garimpos como algo que se aproxima do espetáculo das "carroças de colonos" que se colocam a caminho, que o cinema norteamericano imortalizou, fundando os "povoados do faroeste", dando ensejo a notícias que circulam pela capital do país, como essa: Engenheiro Morbeck (Lageado) era a pequena capital da nova Califórnia que emergia no coração dos sertões do Brasil Central. Nessa mesma linha de encenação figurativa, o rio Araguaia aparece enaltecido como "o Mississipi do oeste brasileiro", levando os nortistas em marcha a cumprirem o seu papel edificador de novos bandeirantes: não tanto no sentido de alargar fronteiras, mas no de descobrir, segundo esta representação, os territórios desconhecidos do Brasil, trazendo à civilização os "vastos sertões".

A descoberta de ouro e diamante em Mato Grosso, iniciada na região de Poconé e Guiratinga, foi estendida posteriormente a Cuiabá e de lá para Diamantino, Alto Paraguai, Nortelândia, Arenápolis e Santo Afonso ${ }^{8}$, tendo a Coroa portuguesa colocado a lupa da exploração em terras mato-grossenses. O processo de ocupação das áreas garimpeiras foi controlado por Portugal, em função da possibilidade de abocanhar fartos recursos via concessão de terras para exploração e das elevadas taxas de impostos cobradas sobre a exploração.

A exploração artesanal e o rigor na concessão de áreas de exploração em desfavor da população trabalhadora e pobre, combinados com as grandes extensões de áreas de exploração que implicava um limitado controle sobre as regiões produtoras de ouro e diamante, acabaram por estimular o crescimento da atividade de exploração mineral por meio do garimpeiro autônomo, o contraventor, fora do controle da Coroa.

Conforme Barrozo (2007), a extração mineral em Mato Grosso iniciou-se por volta de 1719, sendo interrompida na primeira metade do século XIX, em função de um conjunto de circunstâncias, como a descoberta de diamantes, o que provocou o fechamento dos garimpos por parte da Coroa devido às dificuldades de controlar a exploração dessa preciosa pedra, de expressivo valor, ao lado de outros fatores, como: a) dificuldade de acesso ao centro-sul; b) conflitos entre brasileiros e portugueses; c) conflitos políticos internos que desestabilizavam as

8 Os municípios de Diamantino, Alto Paraguai, Nortelândia, Arenápolis e Santo Afonso estão localizados no Sudoeste do Estado, região essa identificada como região Médio-Norte, próximos ao município de Tangará da Serra. 
relações sociais e econômicas na Província; d) reposição de mão-de-obra com o fim do trabalho escravo e ainda e) pelas dificuldades de permanência dos garimpeiros em regiões de difícil acesso e suprimento de produtos essenciais para o consumo, combinado com doenças típicas da região, como é o caso da malária.

Guimarães Neto (2006) aborda a resistência das populações indígenas, pois a colonização não foi pacífica, mas violenta e sangrenta, considerada como um dos entraves para o retardamento da exploração em Mato Grosso em suas várias regiões. Na região do Araguaia ocorreram a resistência Bororo, em direção ao Pantanal Mato-grossense, pelo rio Cuiabá a resistência Paiaguás e em direção à Barra do Bugres, que inclui as terras do Município de Tangará da Serra, a resistência Umutina e Parecis.

Se a exploração mineral em Mato Grosso foi o caminho para o desenvolvimento, foi também o caminho para o avanço privado sobre a posse de terras, inicialmente com as sesmarias e posteriormente pela concessão de terras feita pela Coroa Portuguesa para a exploração garimpeira. Constituíram-se os ricos do garimpo, do comércio e serviços prestados nas regiões garimpeiras, as primeiras elites agrárias e políticas, em conjunto com a estrutura militar e a burocracia advinda da capitania.

Esse primeiro ciclo de exploração mineral em Mato Grosso, apontado por Barrozo (2007), estendeu-se até por volta do início do século XIX, quando entrou em decadência e gerou uma pulverização das concentrações humanas das regiões garimpeiras e pobreza no Estado.

Nesse contexto de crise no garimpo e abertura de novas possibilidades econômicas, ocorre a Guerra do Paraguai, no período de 1864 a 1870. Foram, portanto, seis prolongados anos, constituindo-se no maior conflito armado da América do Sul de que se tem notícia. Naquele período, o território de Mato Grosso se estendia até onde hoje é Mato Grosso do Sul, estabelecendo, assim, fronteira com o Paraguai. Conforme Chiavenatto (1979), assim como o avanço na linha do Tratado de Tordesilhas", a Guerra do Paraguai atendeu a interesses comerciais britânicos, que viam no Paraguai um concorrente regional em função do processo de industrialização em curso naquele país, contrariando os interesses da Coroa Britânica. Junto com os interesses comerciais ingleses, havia os interesses regionais: o Brasil estava interessado na abertura de uma saída pelo Pacífico, facilitando a conexão com a Europa, Argentina e Uruguai interessados em avançar sobre as terras férteis do Paraguai. Estavam dadas as

\footnotetext{
$9 \quad$ O Tratado de Tordesilhas de 1494 constituía-se em uma linha imaginária que dividia os domínios territoriais na América do Sul entre Portugal e Espanha. Posteriormente, no ano de 1720, com a assinatura do Tratado de Madri, as fronteiras entre o domínio espanhol e português na América do Sul foram redefinidas. Agora não mais uma linha imaginária, mas limites geográficos, com marcos definidos, ampliando o domínio português para a região Norte, grande parte do Centro Oeste e praticamente a totalidade da região Sul do Brasil. O início da exploração mineral em Mato Grosso coincidiu com a assinatura do Tratado de Madri no ano de 1720.
} 
condições, sob a égide dos interesses ingleses, de construir a tríplice aliança: Brasil, Argentina e Uruguai, para guerrear contra o emergente país Paraguai.

Ao final da guerra, segundo Chiavenatto (1979), o que se viu foi o aniquilamento por completo do Paraguai - aniquilamento industrial, bélico e humano. A última resistência paraguaia foi formada por adolescentes e jovens, praticamente, sendo totalmente extinta a população masculina daquele país. A Guerra do Paraguai ocorreu em um momento de retração da atividade garimpeira em Mato Grosso, o que acabou por aprofundar a crise, em função dos riscos da guerra, principalmente no deslocamento de cargas e pessoas, que tinham como rota principal o rio Paraguai, que era também a principal rota da guerra.

A crise do garimpo estimulou o incremento de outras atividades econômicas, destacando-se entre elas a cana-de-açúcar, voltada à produção de açúcar, álcool e cachaça e o extrativismo vegetal. "O norte redefiniu suas forças produtivas tendo por base a produção açucareira e o extrativismo, atividades estimuladas pela utilização de uma nova aquavia[...], [...]a abertura da navegação pelo rio Paraguai (1856)". (MORENO, 2007, p. 36/37).

O sul-mato-grossense teve uma outra dinâmica de desenvolvimento, a partir da região norte de São Paulo, com predomínio da atividade pecuária. Conforme Moreno (2007), as incursões vindas de São Paulo, especialmente de Franca, foram responsáveis pelo desalojamento das populações nativas, com a apropriação e implantação de grandes fazendas, voltadas à criação de gado. "O desenvolvimento da pecuária foi responsável, no século XX, pela constituição da elite política da região sul do estado" (MORENO, 2007, p. 40).

Norte e sul-mato-grossense historicamente se antagonizaram em relação às disputas políticas, calcadas nas oligarquias rurais que se formaram ao longo do processo de exploração das terras mato-grossenses: o norte com um oligarquia que se originou no garimpo e se expandiu para o domínio das terras, voltadas à produção açucareira e o sul, com uma oligarquia que se formou com base no domínio das terras, com características de exploração pecuária e de exploração de ervas naturais.

Conforme Barrozo (2007), a retomada da atividade garimpeira nas regiões de Diamantino e Alto Paraguai, extensiva às regiões de Nortelândia, Arenápolis e Santo Afonso, deu-se na primeira metade do século XX, praticamente após 100 anos de abandono da atividade.

Aqui importa ressaltar que, durante o período de desmobilização da atividade garimpeira, em algumas regiões, como é o caso da região sudoeste, sua dispersão acabou por influenciar o início de outra atividade e estimulou o avanço para as áreas de matas: era a cata 
da poaia ${ }^{10}$, planta rasteira nativa das matas tropicais, principalmente na beira dos córregos e rios. A exploração da poaia foi importante, pois permitiu fixar boa parte da população remanescente do garimpo e estimulou o conhecimento e abertura de novas fronteiras, até então desconhecidas, via fluvial, através do Rio Paraguai e Sepotuba. Possibilitou o conhecimento de grande parte das áreas do Município de Tangará da Serra, região de terras férteis, posteriormente ocupadas com projetos de colonização privados.

O Município de Tangará da Serra é cortado e banhado, em grande parte de sua extensão, pelo Rio Sepotuba, um dos principais afluentes do Rio Paraguai, o que gerou uma importante rota fluvial de acesso ao Município, em direção centro-sul/sudoeste, acesso para as caravanas que vinham sentido Rio Paraguai-Tangará da Serra e região noroeste. O Rio Sepotuba constituiu-se em importante rota de acesso à região de Tangará da Serra rumo ao noroeste do Estado e norte do país, precisamente em direção aos Estados de Rondônia e Acre.

Em meados do século $X X$, a região passou por um paradoxo, de um lado, o reinício da exploração mineral consorciada com a exploração da poaia, conjugada com iniciativas de assentamentos privados de minis e pequenos produtores rurais, como é o caso de parte do Município de Tangará da Serra, de outro, a implantação de um projeto modernizante de exploração do campo, estimulada por uma política governamental de incentivos (financiamentos a juros modestos e isenções fiscais) às atividades de agricultura e pecuária em conjunto com a exploração madeireira, privilegiando o latifúndio rural.

\footnotetext{
10 Conforme Marien (2008), trata-se de um arbusto pequeno de significativo valor medicinal, o que lhe confere um alto valor comercial, destinado principalmente ao mercado europeu. Era abundante nas regiões de matas tropicais, principalmente nas beiras dos rios e banhados. Sua exploração era realizada com extrema dificuldade, pois exigia dos poaeiros enfrentar as densas florestas em período chuvoso, expondo-se às doenças típicas das florestas tropicais como a malária e a leishmaniose, além de mosquitos, pernilongos e exposição a animais peçonhentos como cobras e aranhas. Sua exploração era concentrada no período chuvoso pois o arbusto devia ser arrancado com as raízes, necessitando que a terra estive úmida para sua extração. $\mathrm{O}$ valor medicinal concentrava-se nas raízes, razão pela qual era necessário arrancar o arbusto puxando-o com as mãos. Não era possível efetuar a exploração no período de seca, quando não havia umidade na terra, impedimento para que o arbusto fosse arrancado com suas raízes.
} 


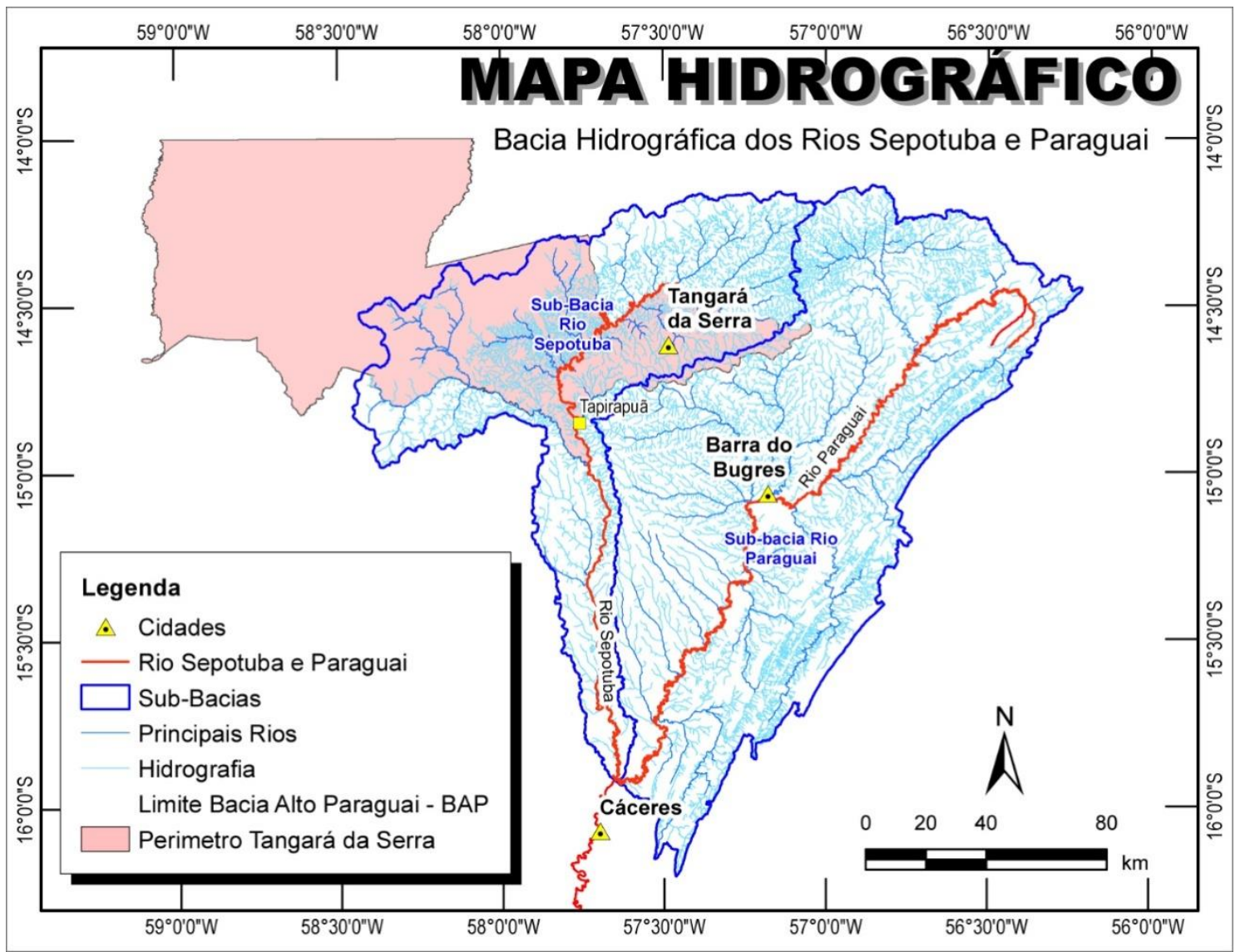

Fonte: Por Almir José Azevedo, desenhista técnico cartográfico. Cartas Topográficas IBGE/DSG, Imagens SRTM (Shuttle Radar Topography Mission).

\section{Figura 03 - Mapa hidrográfico identificando o Rio Paraguai e o Rio Sepotuba, principais rotas da cata da poaia}

Ao longo do processo de colonização as populações indígenas recuaram para o alto parecis e as tradicionais de poaeiros, originárias da dispersão do primeiro ciclo do garimpo, foram dizimadas e expulsas das terras que ocupavam, empurradas por fazendeiros, pelas empresas loteadoras e loteadores autônomos das áreas rurais que ocuparam.

\section{0 caráter modernizante da agricultura no Centro-Sul brasileiro, o caminho do Norte e a resistência dos sitiantes}

Conforme Silva (1999), a política agrária nacional com caráter modernizante implementada no período ditatorial, em grande medida, pautou-se pelo processo de expropriação de significativas parcelas da população rural de suas terras e da ocupação de extensas áreas de terras devolutas, como foi o caso do Estado de Mato Grosso, demonstrado 
por Moreno (2007). Silva (1999) mostrou que se tratava de um processo de planificação do desenvolvimento econômico nacional, com fulcro no processo de modernização da atividade econômica, com significativos reflexos no campo.

O Estado brasileiro, pós Golpe Militar, considerando o governo federal e os governos estaduais, do ponto de vista da legislação, construiu as condições objetivas exigidas pela modernização, em perspectiva capitalista. $\mathrm{O}$ arcabouço de leis que regulava a relação do homem com a terra, notadamente a Lei de Terras, $\mathrm{n}^{\circ}$. 601 de 18.09.1850 do período imperial, o Estatuto do Trabalhador Rural (ETR) de 1963 e o Estatuto da Terra (ET) de 1964 tiveram como efeito prático serem instrumentos a favor do processo de concentração de terras.

A modernização no sudeste do país, baseada na concentração de terras para a implantação de monoculturas - como as florestas exóticas para produção de celulose e a implantação das lavouras de cana-de-açúcar para suprir as indústrias do setor sucroalcooleiro , combinada ainda com o processo de maquinização das práticas agrícolas no campo, gerou uma multidão de expropriados das terras. Verificou-se a ruptura de uma forma tradicional da relação de homens e mulheres com a terra e o estabelecimento de um modelo concentrador pautado em monoculturas, que acabou por gerar uma massa de trabalhadores rurais expulsa de suas terras. "Baseando-se nos projetos modernizantes, todo um mundo assentado em relações específicas com a terra e dos homens entre si foi determinado a desaparecer". (SILVA, 1999, p. 45).

"No período de 1960-1980, foram expulsos 2,5 milhões de pessoas do campo paulista". (SILVA, 1999, p. 63), contingente que acabou tendo como alternativa a migração para os grandes centros, onde se desenvolvia a todo vapor o processo de modernização urbana via industrialização ou a migração para outras regiões brasileiras, tendo Mato Grosso como um dos caminhos, na busca de conquistar um pedaço de terra.

Mato Grosso já vinha com um histórico de concentração de terras iniciado no período imperial para exploração das atividades garimpeiras, por meio das sesmarias e das concessões de terras para exploração mineral fornecidas a agentes privados com capacidade financeira suficiente para organizar as atividades de exploração, sob forte influência dos lobbies das oligarquias que se formavam para avançar sobre as terras do Estado, processo estendido até o início da república. Com o advento da república, em 1889, o pacto federativo transferiu para os estados a prerrogativa de legalização das terras rurais, passando o mesmo, a partir de então, a ser o responsável por implementar as políticas de regularização e concessão de terras. No caso específico de Mato Grosso, estavam estabelecidas as relações de poder, formadas pelas elites 
do sul e do norte, constituídas basicamente por militares, burocratas, comerciantes, grandes proprietários e grandes posseiros de terras (as oligarquias rurais).

Com a constituição de 1891, no artigo 64, regulamentada pela Lei de Terras do Estado, de 1892, as terras devolutas, até então sob a jurisdição federal, passaram para a jurisdição estadual. A partir daquela lei, a elite política e econômica do estado foi se apropriando privadamente das terras públicas situadas no Estado de Mato Grosso. (BARROZO, 2010, p. 11).

Para tanto, tratou o Governo de Mato Grosso com base na Lei n ${ }^{\circ} 601$ de 1850, denominada Lei de Terras, e nas Leis Estaduais $\mathrm{n}^{\circ} 20$ e $\mathrm{n}^{\circ} 24$ em 1892, de regulamentar o processo de concessão das terras do Estado. A Lei n ${ }^{\circ}$ 20, conforme Moreno (2007), tratou dos processos de regularização fundiária, e a Lei $\mathrm{n}^{\circ} 24$ criou um órgão estadual específico para a regulamentação, a "Diretoria de Obras Públicas, Terra, Minas e Colonização". Essa regulamentação, em conteúdo, tem semelhança com a Lei nº 550, de 20 de dezembro de 1949, do Estado de Minas Gerais, à medida que prioriza a regulamentação de áreas já ocupadas: “a Lei $n^{\circ} .20$ dispunha sobre os processos de revalidação das sesmarias, legitimação das posse e venda das terras devolutas [...] (MORENO, 2007, p. 65). Do ponto de vista prático, significou o avanço das oligarquias, utilizando-se do aparato do Estado, sobre as terras devolutas do Estado.

Semelhante ao que ocorreu em São Paulo, narrado por Silva (1999), a Lei no 20 obstaculizou o acesso e permanência na terra aos pequenos trabalhadores rurais, por dificuldades de enfrentar a burocracia para a regulamentação de suas posses e até, de requerer posses, apesar de a Lei garantir a gratuidade na concessão de área de até 50 hectares. "O total geral de terras alienadas, conforme dados levantados de 1822 a 1929, correspondeu a 48.942.292,5 hectares [...]. É interessante verificar que as concessões gratuitas, concedidas no mesmo período, num total de 149 concessões, não chegaram a somar 5.000 hectares de terras" (MORENO, 2007, p. 73), uma média de 33,56 hectares por produtor ou família.

Esses dados são explicativos das relações sociais no campo e do privilégio histórico que as elites políticas e econômicas tiveram no processo de ocupação do território brasileiro, fenômeno nacional, porém, com forte incidência no Estado de Mato Grosso. Do total de terras alienadas para agentes privados, somente $0,01 \%$ destinou-se a minis e pequenas propriedades.

O campo mato-grossense já era constituído majoritariamente de grandes latifúndios, ficando os possuidores de pequenas propriedades rurais expostos às pretensões dos grandes proprietários que avançavam sobre essas terras, expulsando os pequenos produtores, com 
compras diretas a preço vil ou por meio da expulsão via intimidação. Os conflitos no campo em Mato Grosso eram comuns. Prevalecia, em grande medida, o poderio do latifúndio em um Estado onde as oligarquias rurais eram também o poder político.

A remodelação da forma de acesso à terra a partir da década de 50 deu-se praticamente por meio de vendas, em função do interesse e da necessidade do Estado em arrecadar. É nesse contexto que se processou o avanço para a região sudoeste do Estado e aqui estamos falando precisamente da região de Tangará da Serra, que se coloca entre as Serras Itapirapuã e do Parecis. Apesar de inicialmente as terras do local terem sido apropriadas por latifundiários e especuladores, diferentemente de outras regiões do estado, acabou por consolidar, com o passar do tempo, um processo de ocupação fundado nas minis e pequenas propriedades.

\section{A migração para Córrego das Pedras, na contramão da política de concentração}

\section{fundiária}

Na primeira metade da década de 60, coincidindo com o início da ditadura militar, iniciou-se o processo de ocupação das terras do atual município de Tangará da Serra, região de terras férteis, via migração de famílias advindas dos Estados de Minas Gerais, São Paulo, Paraná e de "nordestinos"11. Eram famílias com trajetória de vida no campo, buscando oportunidade de se fixar em um pedaço de terra para trabalhar na roça ${ }^{12}$ e continuar a produção e reprodução de suas vidas. É dentro desse contexto que ocorreu a ocupação das terras da comunidade Córrego das Pedras, com a migração de famílias, principalmente, dos Estados de Minas Gerais e São Paulo.

A migração das regiões sudeste e nordeste para Mato Grosso, de modo particular para Tangará da Serra, se dá em um cenário de crise no campo, aprofundado pelas políticas de modernização do campo implementada pelos governos federal e estaduais. O relato abaixo é demonstrativo das condições de dificuldades em que muitos sitiantes viviam, que dificultavam a possibilidade das famílias de continuarem a produção da vida material em seus locais de origem.

\footnotetext{
11 Entende-se "nordestinos" todos os migrantes que vieram de algum estado do nordeste brasileiro, identificados em função de suas características regionais como "falar nordestino", a "comida típica", as expressões artísticas como cantorias, poesias regionais, música e a tradicional prática da vaquejada. Em Tangará da Serra, na década de 80, eles constituíram o CTN (Centro de Tradições Nordestinas), espaço social utilizado para as confraternizações e manifestações culturais, identificandoos como uma unidade grupal.

12 Caracterizava o trabalho de lavrar a terra em pequenas porções que consistia na derrubada de mata virgem de forma manual e posterior queimada, com o concomitante plantio da lavoura de arroz. Após a colheita, no mesmo ciclo, na palhada do arroz, o plantio da roça de milho ou feijão. Denominava-se "roça de toco", porque a plantação era feita de matraca (equipamento de plantio manual de sementes) no meio de galhadas grossas e toras derrubadas não pulverizadas pelo fogo, quando da realização da queimada.
} 
A coisa estava feia para nós. Lá nós íamos acabando com tudo. Era muita gente que não tinha nada e nem tinha o que fazer. Chovia pouco, só até final de dezembro e início de janeiro. Já não produzia nem o milho. Eu tinha pouca coisa, um pouquinho de gado que tinha que vender para comprar as coisas para comer. Já não tinha quase mais nada, rapaz. Eu pelejei uma vez com uma selaria. Fiquei uns quatro anos, mas ninguém tinha dinheiro para comprar nada e dava prejuízo, e eu parei com aquilo. Eu tinha cinco moleques e tudo que eu fazia não dava certo. Eu falei: "Deus vai mostrar para nós um lugar bom, que chove e produz para nós criarmos nossos filhos, porque aqui tá perigoso passarmos fome", porque não tinha nada de serviço para ganhar dinheiro. No sítio era só quiçaça, saroba, já não produzia mais nada para ganhar dinheiro. (Entrevista com o Senhor Arestides, em dezembro de 2016).

O relato acima evidencia as dificuldades da vida camponesa no interior de Minas Gerais, marcada pela escassez de serviços e pelo baixo valor da mão de obra, impeditiva, do ponto de vista do Senhor Arestides, de garantir sua sobrevivência e da família. Ele buscou outras alternativas, como a profissão de celeiro, porém não conseguiu sobreviver, pois a pobreza da região em Minas Gerais era tamanha que não conseguia produzir e vender o suficiente para tratar de sua família. Ele fala que era desesperadora a situação, não só dele, mas também de parentes e amigos, em função da pobreza da região. Poder-se-á perceber essa forma de compreensão quando ele diz que "ninguém tinha dinheiro para comprar e dava prejuízo", sinalizando o risco de passar fome junto com sua família. O risco e a iminência de faltarem as condições de sobrevivência material da família impulsionaram os processos migratórios.

A pobreza extrema e falta de perspectiva nos locais de origem, como é o caso de muitas famílias migrantes do Estado de Minas Gerais, e o processo de modernização das práticas agrícolas em São Paulo, que expulsaram milhares de famílias do campo, são fatores explicativos do processo migratório massivo que ocorreu na região nas décadas de 60 e 70 . O pano de fundo desse processo foi a busca de melhores condições de vida por parte dos migrantes para produzirem a própria subsistência e a da família. Importa perceber que não se trata de uma dificuldade pontual e passageira. "Quando os migrantes falam que a vida em Minas estava difícil, referem-se a uma situação permanente de dificuldade. Não enxergam possibilidade de mudança”. (LUCENA, 1999, p. 40). É um cenário de dificuldade e desolação permanente, evidenciado no depoimento do Senhor Arestides.

Conforme relatos dos entrevistados, não havia um local específico de chegada das migrações. Muitas vezes, sequer sabiam para onde iriam. No início da década de 60 , algumas 
famílias migrantes acabaram parando no sul mato-grossense, atualmente Estado de Mato Grosso do Sul.

Nós vínhamos pelo rumo, em sete famílias em um caminhão "pau-de-arara"13. Seis dias de viagem, chegamos em Fátima do Sul, no Município de Dourados, no Sul de Mato Grosso, pois naquela época era um Estado só. A turma olhou para um lado para outro e disse: "que lugar bom, dá para a gente ficar aqui “. A turma estava cansada, aquele tempo a viagem eram em "pau de arara". A maioria era estrada de chão, só no estado de São Paulo tinha estradas asfaltadas, mas o trecho que viajamos naquele Estado era pequeno, pois passava somente em um canto. Para cá era muito chão. A turma disse, "Senhor Pacheco", que era o nome do meu pai, "ou compadre, vamos ficar por aqui". Nós vínhamos pelo rumo. Nós saímos de Itanhomi (MG) para ir para Mato Grosso, meio no rumo. Mato Grosso era muito falado. Meu pai falou que tem um lugar de Mato Grosso por nome Jangada, nós vamos para lá. Até hoje eu ainda lembro de Jangada, que era o lugar que nós íamos parar primeiro. (Entrevista com o Senhor Gentil Pacheco, em janeiro de 2017).

Esse depoimento mostra a disposição para a migração e as condições em que se realizavam. Muitas famílias em um caminhão revelavam o grande fluxo de migração, em caminhão pau de arara - na carroceria de caminhões, com o mínimo de mudança, pois era necessário transportar várias pessoas. A referência ao local chamado Jangada - próximo a Cuiabá - e a parada no sul mato-grossense são reveladores do cansaço de uma viagem feita de modo dificultoso, por caminhão, em estradas de terra, encerrando a viagem em algum lugar, antes do destino final.

Praticamente todos migravam com o núcleo da família: esposa, filhos e, muitas vezes, irmãos, irmãs e outros parentes. Os "paus de araras" sempre se deslocavam com um amontoado de famílias. O núcleo migrante presente na comunidade Córrego das Pedras - pais, mães, irmãos e irmãs -, foi basicamente formado com homens e mulheres de meia idade, com parte da família constituída (no caso do Sr. Arestides, que tinha cinco filhos e depois teve mais cinco em Tangará da Serra), com expectativa de construir vida melhor e futuro para seus filhos, portanto, eram relativamente jovens.

13 O termo advém do transporte de aves e pássaros, incluindo araras, empoleirados em um pau, em gaiolas adaptadas em carrocerias de carroças de animal, caminhonetes ou caminhões. Consistia em um meio de transporte muito utilizado nos processos migratórios regionais. Esse é um termo definidor de condições precárias para viagem. Tratava-se de um caminhão, em que, após fazer a elevação da carroceria com madeira ou barras de ferro, a mesma coberta por lona, espalhavam-se os colchões e malas de mudanças no assoalho para acomodação das famílias, o quanto coubesse. 
No início, ainda na década de 50, as terras foram apropriadas por empresas imobiliárias do Estado de São Paulo. No caso da região de Tangará da Serra, nas terras entre as serras do Tapirapuã e do Parecis (parte baixa), o processo de colonização se deu principalmente com a empresa SITA. A empresa adquiriu as terras diretamente do Estado ou de terceiros que já tinham adquirido do Estado, para posteriormente serem fracionadas e comercializadas.

As terras da comunidade Córrego das Pedras estão contidas nas matrículas (R-5137-A, R-7237, R-6481 e R-4004), tendo duas (R-5137-A, e R-6481) sido adquiridas por japoneses ou seus descendentes, fato que considero relevante. No início da colonização das terras do município de Tangará da Serra na região localizada entre a serra do Tapirapuã e o Rio Sepotuba, no Baixo Parecis, os japoneses foram os primeiros adquirentes da maior parte das terras.

Oliveira (2012) chamava a atenção para a presença de japoneses ou seus descendentes como primeiros adquirentes das terras do município de Tangará da Serra, no início da década de 50, incorporando uma área total adquirida por japoneses de 184.531,00ha. Conforme o autor, Kubo Sakuyoshi, agrimensor paranaense, veio à região de Tangará da Serra, em 1956, para conferir e marcar as terras adquiridas pelos japoneses. Na ocasião, entrou em conflito com posseiros e, em emboscada no município vizinho de Nova Olímpia, quando retornava ao Estado do Paraná, foi assassinado. O assassinato premeditado do primeiro japonês de quem se tem notícia de ter colocado os pés na terra dos Tangarás pode ter desestimulado a migração japonesa para a região que, em função do risco, acabaram por vender suas posses a preço vil ou abandoná-las, abrindo espaços para muitos litígios por posse e propriedade de terras.

Outra versão sobre a presença japonesa na região é dada por um pioneiro da região, que participou do processo de colonização:

A colonização aqui iniciou na época do Presidente Getúlio Vargas, sendo que era para serem assentados nesta região 27.000 famílias japonesas. Os japoneses não vieram para cá por causa da guerra. O Japão foi contra a aliança liderada pelos EUA e perdeu a guerra. Na época tinha um japonês chamado Matswubara, de Marília, que era aliado do Presidente Getúlio Vargas, tinha influência no governo e interesse na região. Após o suicídio de Getúlio Vargas, mudou o cenário político. Esse tal de Matswubara teve que fugir e cancelaram a migração dos japoneses. Com a derrota da aliança do eixo na guerra, os japoneses ficaram impedidos de deslocar de qualquer lugar no Brasil. Naquela época, os japoneses mais capitalizados no Brasil, era a turma do Paraná: o Matswubara, que tinha acesso aos títulos aqui dessa região de Mato Grosso, vendeu tudo para os japoneses do Paraná e fugiu. A maioria dos 
compradores das áreas aqui de Tangará era do Paraná. Porém esses japoneses, impedidos de deslocar no país, venderam esses títulos. (Entrevista com o Senhor Wilson Galli, em maio de 2018).

Trata-se de uma versão que traz elementos que dificultavam a migração japonesa para uma região próspera, onde foram os primeiros proprietários das terras, conforme demonstram os documentos cartorários, confirmados no depoimento de um loteador.

Esses fatos demonstram que a ocupação do território do município no Baixo Parecis não foi tranquila e notícias de grilos e litígios por disputas de terras, até com mortes, durante muito tempo, fizeram parte do processo de colonização.

Conforme Moreno (2007), nas décadas de 50 e 60, quando se intensificaram os processos de vendas de terras pelo Estado, eram comuns os casos de usurpação de imensas extensões de terras públicas, os tradicionais e conhecidos "grilos". Tal prática era assegurada, em muitas situações, pela regularização por meio do Estado, em função da influência política das elites agrárias. Tratava-se de um processo de grilagem, ancorado em um poder político, que se colocava a serviço dos grandes proprietários de terras.

Importante fato ilustrativo nos achados de pesquisa é a matrícula R-4004, registrada no Cartório de Registro de Imóveis de Barra do Bugres, área com 5.860 ha adquirida do estado de Mato Grosso por Euclides Borges Leal, em 19 de novembro de 1953 e posteriormente alienada por compra direta aos senhores Fábio Liserre, Júlio Martinez Benevides e Joaquim Oléa. Esses últimos dois senhores eram sócios da Empresa SITA Sociedade Comercial e Imobiliária Tupã para a Agricultura, loteadora de grande parte do território do município de Tangará da Serra. Conforme consta na matrícula, após a alienação aos sócios da Empresa SITA, foi feita uma revisão da área que a ampliou para 9.870 ha, correspondente a 59,37\% de ampliação, majorando a área originalmente adquirida do Estado em 4.010 ha. Essa aquisição se deu em 19 de novembro de 1953 e a averbação da ampliação, em 13 de abril de 1960, portanto, mais de sete anos após a primeira aquisição. Tal ampliação de área constituiu-se em indicativo de fraude. Moreno (2007) já apontava para tratativas fraudulentas no interior dos órgãos de regularização fundiária do Estado de Mato Grosso, com o propósito de ampliar o quantitativo das áreas adquiridas do Estado, que já se constituíam em latifúndios.

Pelo tamanho do corte das glebas que compuseram originariamente o município de Tangará da Serra, percebe-se que estava dentro do processo de expansão prevista para Mato Grosso. Isso significa uma política agrária voltada para grandes propriedades. Foram as iniciativas do mercado especulativo imobiliário, associadas a um grande fluxo de camponeses expulsos de suas condições de trabalho no centro sul brasileiro, que possibilitaram a mudança 
de rumo do processo de colonização, como foi o caso de Tangará da Serra. Boa parte das grandes propriedades passaram a ser fatiadas para comercialização de terras no campo, enquanto, paralelamente, se iniciava a implantação de um pequeno povoado, o distrito de Tangará da Serra, pertencente ao município de Barra do Bugres (MT). Estávamos diante de um processo de colonização com base nas minis e pequenas propriedades que acabou por estimular a formação de inúmeras comunidades rurais na região, incluindo a comunidade de Córrego das Pedras.

O fato é que, em função da qualidade das terras e do clima, com possibilidade de produção de café, a especulação imobiliária possibilitou que boa parte da região fosse loteada em minis, pequenas e médias propriedades, com o propósito de aproveitar o surto migratório dos Estados de Minas Gerais, São Paulo e Paraná.

Quem colonizou essa região de Tangará foi a turma de Tupã: o Júlio Martinez e o Joaquim Oleas. Eu estudava em Tupã, no colégio Dom Bosco com o filho do Júlio Martinez, o Wanderley. Naquela época, vivia-se o ciclo do café, já era o final do ciclo. Então eles disseram: "descobrimos uma região que não gea e dá café". Ora, isso era a mesma coisa que achar um filão de ouro e diamante. Não gea, dá café e a terra é roxa. Eu falei: "vocês estão doidos, isso não existe”. Eles falaram: “existe, é Tangará da Serra". E eu fui ver, e não é que era mesmo. (Entrevista com o Senhor Wilson Galli, em maio de 2018).

Das famílias migrantes do interior de São Paulo e Minas Gerais para a região de Tangará da Serra, muitas são advindas das expropriações das lavouras de café, extintas com o processo de modernização. Essas famílias eram possuidoras de pequenas propriedades ou tocavam roças como meeiros ou arrendatários. Há, ainda, situações de migrantes que se deslocaram em função do esgotamento das condições de sobrevivência nos locais de origem, provocadas por fracionamento das propriedades pelas partilhas, pelo esgotamento das terras e, ainda, por não terem posses. Esses percebiam em Mato Grosso a oportunidade de conquistarem a terra para o trabalho. Buscaram manter-se no campo, onde tradicionalmente produziram e reproduziram uma dinâmica de vida, quer seja como proprietários de pequenas propriedades, quer seja como arrendatários ou meeiros.

Conforme relato das famílias da comunidade Córrego das Pedras, além do acesso à terra por meio da compra direta, possibilidade para as famílias que vieram capitalizadas, há, também, casos de famílias que vieram para o trabalho no campo e que, no decurso do tempo, obtiveram 
renda nas empreitas de derrubada e de implantação de roças. Assim conseguiram adquirir terras, onde permanecem até hoje. Em situações diversas nos locais de origem, para permanecerem na terra, a saída das famílias foi a migração para Mato Grosso. É nesse contexto que se deu o processo de ocupação das terras de Mato Grosso, a partir da década de 50, com foco nas atividades agrícolas, pecuárias e de exploração de madeiras.

Na região de Tangará da Serra, os primeiros migrantes que ocuparam as terras, foram majoritariamente mineiros e paulistas, com formas de vida e características culturais em comum, visto que a ocupação do território mineiro no século XVII e XVIII se desenvolve nas regiões garimpeiras, a partir do avanço das bandeiras, o que, pela natureza migratória e de exploração, consistia em absoluta aventura, frente aos desafios de explorar e habitar áreas de difícil acesso e com severas limitações alimentares, condições determinantes para a constituição do "caipira"14 (CANDIDO, 1982), homem adaptado às condições mais adversas de sobrevivência. É essa constituição histórica de formação de um tipo de povo que vai repercutir no processo migratório para Mato Grosso, particularmente na Comunidade Córrego das Pedras.

Esses homens e mulheres que migram na busca por melhores condições de vida, foram movidos pelo sonho da conquista da terra. O sentimento produzido pela descoberta da terra boa pode ser notado nos brilhos dos olhos do Senhor Arestides:

Ai quando virou para cá (região do Córrego das Pedras) ele ficou doido. Viu um pé de figueira: era terra boa. E ele falou, "vai lá no Córrego das Pedras, lugar de terra boa, mas de malária". Nem sabíamos o que era a tal de malária. “Ah! é uma febre, mas a gente dá um jeito nela". De fato, terra boa é aqui mesmo. (Entrevista com Senhor Arestides em dezembro de 2016).

O sonho era possuir um pedaço de terra para se estabelecer, para plantar e colher, para garantir a produção e reprodução familiar. De fato, em Córrego das Pedras, encontraram terras férteis para plantar e colher e mão de obra valorizada em função da escassez. Uma região de mata densa, com animais silvestres; intensa chuva, pois a região era provida de um clima com duas estações bem definidas - seis meses de chuva que se estendiam de outubro a março, e seis meses de sol e seca, que se estendiam de abril a setembro -; e as doenças causadas na relação dos homens e mulheres com uma região de matas virgens e clima tropical úmido - a malária e

14 Segundo Candido (1982) o "caipira" é fruto de uma composição racial tipicamente brasileira de Bandeirantes e indígenas, com características culturais específicas. No nosso caso, fazemos a distinção somente para fins de distinguir a migração para a Comunidade Córrego das Pedras dos grupos de Minas Gerais e de São Paulo, que apresentam, em muitos aspectos, características sociais e culturais semelhantes, por serem "caipiras". 
a leishmaniose, doenças típicas de florestas tropicais. Não imaginavam o tamanho da dificuldade, porém, o sonho da terra boa para plantar pulsava.

A migração coletiva de um espaço rural para outro, visto que em um mesmo "pau de arara" viajavam várias famílias, e o encontro no local de destino com outras famílias aparentadas ou não, migrantes de uma mesma região, o que era comum em função do quantitativo de deslocamento, abrandava em muito o isolamento e os sentimentos de perda causados pelo processo de mudança.

O novo espaço, por ser rural, permitiu produzir e reproduzir uma dinâmica de vida que as famílias estavam acostumadas, ajudando na criação de novos laços. A nova vida, em um novo espaço, em um outro tempo, com suas dificuldades, é determinante para o estabelecimento de laços solidários e construção de uma coesão social entre o grupo, necessária para o enfrentamento das dificuldades que as famílias iriam passar.

No começo, quando nós chegamos aqui já era tarde, no inverno, já tinha iniciadas as chuvas e, ainda, sem recursos para tocar lavoura. Chovia todo dia e não dava tempo para preparar a roça. No primeiro ano, eu plantei só para o gasto, uns pedacinhos só para a despesa. Não deu tempo de fazer roça maior, no começo era tudo na enxada. No outro ano que foi aumentando a plantação. Esse meio aqui era derrubado (aponta a direção), agora de uma altura para cima era puro sapé. Todo ano eles colocavam fogo e queimava tudo, então virou sapé. Aqui eles chamavam de quiçaça. Eu pegava na lua minguante e capinava aquelas moitas de sapé e foi acabando a quiçaça e ia plantando mudas de café. Comecei plantando uma muda aqui outra ali e foi aumentando, até formar o cafezal. (Entrevista com o Senhor Manoel, em janeiro de 2017).

O novo contexto trouxe a esperança de uma nova vida, de melhores condições de sobrevivência, transformando a quiçaça e o sapé em lavoura de café, com a força de trabalho do Senhor Manoel e sua família. O Senhor Manoel chegou à comunidade no ano de 1971, com as matas derrubadas e depois da malária, "a febre braba" que abateu sobre a região. Ele fala sobre o fogo, destruidor, que queima tudo, não deixando a terra produzir. O fogo para limpar as matas após a derrubada não é mais o mesmo fogo, que agora queima também a terra e a enfraquece. Sua percepção é que o fogo é destruidor. Na sua fala, ele expressa um conhecimento popular: "eu pegava na minguante e capinava aquelas moitas de sapé e foi acabando a quiçaça". Ele está se referindo à lua minguante, propícia para a capinagem, quando, em virtude das forças da natureza, o mato não cresce, ou cresce menos, substituindo-a pelo fogo, destruidor da 
natureza. Na capinagem, a quiçaça e o sapé se transformam em adubação natural, já o fogo, historicamente utilizado como um meio de subjugar a terra, acaba por preparar a terra para o novo ciclo de quiçaça e sapé, que, se não extraídos com a enxada na lua minguante, florescem com mais força no ano seguinte, sufocando a roça.

As experiências passadas são incorporadas ao cotidiano da vida, condição para a garantia da sobrevivência. Produzir os insumos de primeira necessidade como a rapadura da cana para substituir o açúcar, a gordura por meio da caça e depois com a produção de porcos para consumo doméstico, depender muito pouco da cidade para viver, incluindo a implantação da lavoura, significava trazer as experiências do passado para uma vida presente, em um cenário de absoluta escassez de condições de vida.

Aqui vale lembrar as contribuições de Thompson (2016) ao compreender a história dos homens e mulheres a partir do mundo real, micro, onde se dão e desenvolvem as relações sociais. É no mundo real, no contexto das relações sociais em que viveu, que o Senhor Arestides construiu sua experiência de vida e é em outro contexto social, de plena dificuldade, que ele teve que se valer de suas experiências para sobreviver junto com sua família. A relevância do cotidiano e da história de vida pode não ser compreendida sob a perspectiva das macrodiscussões estruturalistas, porém, pode ser percebida no mundo da cultura, espaço de afirmação das experiências, das tradições, dos hábitos e costumes. A rusticidade da vida caipira e de sua cultura são balizadoras da constituição identitária de uma comunidade que traz as marcas do passado, de um passado campesino de incansáveis lutas para produzir a vida material para si e família e permanecerem na terra.

Os migrantes trouxeram um saber tradicional da arte de lavrar manualmente a terra crua, próprio de quem tem a trajetória de vida com vínculos históricos com a terra. Era o saber-fazer, apontado por Woortmann e Woortmann (1997), que o processo de colonização demandava para a abertura das fronteiras do norte.

Os métodos agrícolas usados eram dos mais rudimentares: tocava-se fogo nas matas, roçava-se, plantava-se e não se mexia nas plantações, até a colheita. Considerava-se más as terras e havia prevenção contra o arado, que ainda hoje persiste, sendo o machado, a foice e a enxada os instrumentos do lavrador. Até bem entrado o século não era outro em todo o país o sistema de tratar o solo, baseado na derrubada: onde não existia mata, não havia lavoura. (FRIEIRO, 1982, p. 126). 
O trabalho era todo manual. Primeiro, derrubar a mata e roçar, com machado e foice, após, queimar a roçada e implantar as lavouras brancas (arroz, milho, feijão) para, após a colheita - que era manual -, implantar a lavoura de café ou pasto. Quando o sitiante tinha recursos, empreitava a derrubada:

Meu pai veio na frente e já empreitou o mato para derrubar e foi nos buscar. Quando chegamos, a derrubada já estava queimada. A planta era feita com matraca e a colheita era manual. Plantava arroz, milho, feijão e o café. No primeiro ano que nós chegamos aqui, plantamos o café. Plantava quatro ou cinco linhas de arroz e deixava uma para plantar o café. Nós plantávamos arroz e café tudo junto. (Entrevista com o Senhor Severino Camilo, em janeiro de 2017).

Nesse processo inicial, os trabalhadores rurais eram alçados a condições sub-humanas de sobrevivência, suscetíveis às doenças próprias da floresta tropical, como malária e leishmaniose. Estavam diante do desafio de ocupar um espaço territorial rural em uma região de difícil acesso e com severas limitações alimentares. Desafio para o "caipira" adaptado às adversidades.

Aqui eu plantei em 1966, na hora de colher veio a malária e eu perdi tudo, quase morremos. No outro ano, em 1967 eu não tinha nada para fazer uma roça boa, fiz uma rocinha pequena, só para o gasto. Em 1968 eu fiz uma roça melhor, uma boa roça, eu fui para Tangará fazer uma compra de mantimentos, comprei uns 25 quilos de cereais e tinha que trazer nas costas, pois eu não tinha nada para transportar. Em 1969 eu comprei duas éguas muito boas e um carrinho novo, foi uma coisa louca de boa, e eu pensei, agora vou melhorar a situação. Quando foi em 1970 já pegou outra malária, aquela que morreu muita gente. Eu tinha uns cinco alqueires de arroz plantado ali perto da igrejinha, baseado em uns 600 sacos de arroz. Foi o arroz madurar e a malária nos pegou, eu e a família. Fomos todos para a cidade e ficamos em um ranchinho velho por uns 30 dias. Quando eu voltei não tinha mais nada, o arroz já tinha madurado e caído, tinha apodrecido tudo. Foi eu trabalhar para os outros de novo. Foi uns oito anos de dificuldades. (Entrevista com o sitiante Senhor Arestides em outubro de 2017).

O depoimento é ilustrativo das dificuldades iniciais dos sitiantes, severamente castigados pela exposição a doenças, pela falta de infraestrutura básica e pela pobreza de muitas famílias que migravam apenas com as roupas e a disposição para o trabalho. O Senhor Arestides 
fala da malária que se abateu sobre si e sua família nos anos de 1966 e 1970, impossibilitandoo para o trabalho em momentos cruciais na condução da lavoura. A proliferação da doença se dá, principalmente, no período chuvoso, período de cuidados e até a colheita das lavouras, causando severos prejuízos para quem buscava ainda se estabilizar no trabalho da roça. Ele teve que voltar a trabalhar para terceiros, para garantir a sobrevivência familiar e criar a mínima condição de implantar as lavouras dos anos seguintes, que acabavam sendo mais limitadas, praticamente para o consumo próprio, sem perspectiva de comercialização.

Bosi (2004) fala das memórias de Alice contadas do seu tempo de criança que, transitam das brincadeiras às dificuldades da trajetória de sua viva, mantendo vivos nas suas lembranças os efeitos da gripe espanhola, uma doença devastadora que muito a assustava, pois matava muitas pessoas e não havia providência.

Para Bosi (2004), o narrador vence distâncias no espaço e, aqui, pode-se dizer também, no tempo, para contar as aventuras e desafios da vida, muitos deles de absoluta dificuldade, como foi o enfrentamento da malária narrado pelo Senhor Arestides, bem como o enfrentamento da gripe espanhola narrado por D. Alice. Para Bosi (2004), essas memórias são geradoras de conhecimento, são experiências de vida dos narradores, que se tornam experiências para os que escutam.

A abertura da região é anterior à atividade do comércio, o que contribuía para o aprofundamento das dificuldades, face à inexistência de suprimentos básicos de alimentação, de equipamentos para o trabalho, de transporte, combustível para transporte e geração de energia, remédios, roupas, entre outros produtos e serviços de primeira necessidade.

O Senhor Arestides faz um relato com bastante detalhamento das dificuldades encontradas por ele e pela família:

O caminhão ainda não subia na serra quando nós iniciamos fazendo a roça. Tinha vez que você ia lá na cidade comprar e não tinha nada e, quando tinha, era muito caro e produto muito ruim. Quando nós chegamos, o compadre Manoel e o Tião do Reis vieram e compraram a terra e empreitaram para mim. Quando eles vieram não era tempo de chuva ainda e o cuiabano que tinha um caminhão tipo F.4000 era quem trazia mercadoria aqui, mas, quando nós voltamos já era o fim das águas, não subia nada na serra, eu fiquei na Barra do Bugres quatro dias esperando, quando conseguimos uma carona para Nova Olímpia. Na Barra do Bugres, que era a sede do município, eu comprei uns quatro litros de óleo e umas coisinhas mais, que duraram uns 30 dias. Aqui em Tangará não tinha nada para comprar. Eu falei para o Zé Norberto, meu 
companheiro de roçada: "vou lá na cidade comprar uns mantimentos, pois o que eu trouxe já acabou", e ele falou: "não precisa ir que não tem, lá não tem nada". O que fazer? A coisa mais triste, levantávamos cedo para ir para a roça, e nós trabalhávamos, na foice e no machado, serviço pesado, e não tinha nada para comer, não tinha óleo, carne e açúcar. $\mathrm{O}$ arroz ainda tinha, eles vendiam para nós um arroz ardido e em casca. O nosso descanso do domingo era para socar aquele arroz, fedendo a mofo. Cozinhava ele e comia, pois não tinha mais nada, nem sal e nem gordura. O café eu ainda havia trazido um pouco, um café margoso, sem jeito de beber. Triste rapaz, você levantava de manhã cedo e não tinha o cafezinho para beber, pois não tinha açúcar. Nós tomávamos um golinho de água, pegava as ferramentas, pegava a garrafa de água e ia embora para a roça e só voltava meio dia para fazer o almoço, mas não tinha nada para comer. Colocava aquele arroz ardido dentro da água, purinho, sem nada, cozinhava e engolia aquilo e voltava para roça. (Entrevista com o Senhor Arestides em outubro de 2017).

O relato acima demonstra as dificuldades vividas no processo de colonização, como a inexistência de infraestrutura e de comércio regular e a ausência do poder público, em uma região de mata densa a $80 \mathrm{~km}$ de distância da cidade de Barra do Bugres, sede do município.

A precária situação na comunidade foi resolvida somente no ano de 1974, quando o Governo do Estado abriu caminho através da Serra Tapirapuã, ligando Tangará da Serra a Nova Olímpia, Barra do Bugres e Cuiabá, em melhores condições de trafegabilidade.

Desde a migração e ocupação da área iniciada na primeira metade da década de 60, os sitiantes conseguiram sobreviver em suas propriedades, hoje já na terceira geração. Ao longo do tempo, além do enfrentamento das intempéries, como ausência de mercado, falta de mantimentos e remédios, ausência de infraestrutura básica como transporte, moradia, energia elétrica, entre outras dificuldades, tiveram que reordenar suas práticas produtivas.

As lavouras brancas (arroz, milho e feijão), faziam parte do processo inicial de derrubada, queimada e implantação das mesmas, para posteriormente implantar a lavoura de café, que teve seu ciclo por um prolongado período, porém, esgotou-se, em função, principalmente, das inadequações climáticas e dificuldades de comercialização.

O fim do ciclo do café exigiu novas práticas e novos saberes e, para permanecerem em suas terras, tiveram que descobrir alternativas de se relacionarem com a terra, construindo novos saberes. Woortmann e Woortmann (1997, p. 177), já alertavam para o fato de que “[...] o saber-fazer camponês não é estático. Através de gerações ele acumula experiência e pode, em 
certos momentos, retomar técnicas desenvolvidas no passado [...]”. A experiência dos agricultores da Comunidade Córrego das Pedras demonstrou a capacidade dos sitiantes de produzir novos saberes-fazer e ampliar o conhecimento e a relação com a terra.

A substituição da lavoura do café deu-se de forma gradual. Os sitiantes foram criando e investindo em outras alternativas produtivas, à medida que foram diminuindo os cafezais. Um dos caminhos foi consorciar as produções de hortifrutigranjeiros e legumes com a pecuária de leite e corte. Tiveram que reordenar as práticas produtivas, adequando a produção às necessidades de comercialização na feira e tiveram que se estabelecer como feirantes.

A feira, que ocorre às quartas-feiras e aos domingos, em um espaço adequado de 8.100 metros quadrados, totalmente coberto, acabou se constituindo em importante estratégia de sobrevivência e de permanência na terra por parte dos sitiantes. Parte significativa da população tangaraense adquire os produtos para a alimentação familiar na feira, visto tratar-se de produtos de boa qualidade e frescos, produzidos e fabricados nos sítios. É um ponto tradicional de encontros, de conversas e de visitação turística, tendo à disposição uma praça de alimentação de produtos frescos, cozidos ou fritos na hora, como pamonhas, tapiocas, pastéis, sucos naturais, refrigerantes e o tradicional café coado na hora.

É um espaço tradicional e reconhecido pela população tangaraense como o local de comprar bons e saudáveis produtos para a alimentação, tendo frutas e verduras em abundância, carnes suínas, bovinas, de aves de criação (frango e frangas abatidos); leite e derivados do leite; pães, bolachas e bolos caseiros; rapadura, melado e açúcar mascavo, macarrão caseiro, café moído no ato da compra, artesanatos diversos, mudas de flores diversas, compotas de frutas, doces e conservas de pimentas, ervas medicinais, condimentos diversos, enfim, uma grande variedade de produtos da roça ou produzidos artesanalmente.

A prevalência de uma política migratória estatal comprometida com um modelo que privilegiava as grandes concentrações de terras não conseguiu colocar fim à disposição de muitos camponeses de buscar alternativas de manter o vínculo com a terra e continuar a produzir e reproduzir a existência pessoal e de sua família no campo. No contexto de Córrego das Pedras, o mundo caipira não se dissolveu, mas teve que se adequar às condições do seu tempo. Agora, além de novas práticas produtivas, o sitiante transformou-se em comerciante, passando a vender o resultado de sua produção diretamente na feira.

A luta por parte dos sitiantes da Comunidade Córrego das Pedras é cotidiana, ao longo do tempo precisaram reinventar as práticas produtivas para sobreviverem e permanecerem em seus sítios. Passaram a praticar a policultura: hortifrutigranjeiros, legumes e pecuária, associado 
à produção industrial artesanal dos derivados da produção e comercializarem diretamente na feira.

A trajetória dos sitiantes da Comunidade Córrego das Pedras constitui-se em uma forma de resistência, organizada com base na realidade em que vivem. Diante da impossibilidade de continuar a produção e reprodução das condições de vida nos locais de origem, a migração do camponês com sua família para regiões a serem colonizadas foi a alternativa utilizada. Ao longo do tempo, reinventaram formas de produção e de relação com a terra, produzindo e reproduzindo um modo de vida que os possibilitou permanecerem em suas terras.

Trata-se de um processo de resistência não intencional e sem padrões de organização visíveis de um enfrentamento, ressalta tratar-se de uma resistência de seres pensantes, providos de consciência. Lembra-nos Scott (2011, p. 6): “como estou procurando entender a resistência de seres sociais pensantes, dificilmente posso ignorar sua consciência - o significado que eles atribuem a seus atos. [...]. Por parcial ou imperfeito que seja seu entendimento da situação, eles são dotados de intenções, valores e intencionalidades que condicionam suas ações”.

Para Scott, (2002), entender as formas corriqueiras de resistência é entender o que grande parte do campesinato faz para defender seus interesses da melhor forma que consegue fazê-lo, englobando ideias ou intenções que negam as bases da dominação.

Essas demandas e reivindicações têm normalmente a ver com o nexo material da luta de classes - a apropriação da terra, do trabalho, dos impostos, das rendas, e assim por diante. Onde a resistência cotidiana se distingue mais evidentemente de outras formas de resistência é em sua implícita negação de objetivos públicos e simbólicos. Enquanto a política institucionalizada é formal, ostensiva, preocupada com a mudança sistemática e de jure, a resistência cotidiana é informal, muitas vezes dissimulada, e grande medida preocupada com ganhos de facto imediatos. (SCOTT, 2011, p. 4).

Scott (2002) refere-se a um movimento de resistência que não está relacionado com movimentos políticos amplos, ideologias, ou estrutura revolucionária, mas formas de luta que se dão e desenvolvem na esfera local, ligadas às necessidades históricas de produção da vida material dos sujeitos que vivem na terra, ou seja, ele está se referindo à sobrevivência do camponês e sua família. "Requerem pouca ou nenhuma coordenação ou planejamento; sempre representam uma forma de auto-ajuda individual, evitam geralmente, qualquer confrontação simbólica com a autoridade ou com as normas da elite'. (SCOTT,2002, p. 12). 
Na mesma via de Scott (2002), Thompson (2016) analisa os movimentos da resistência plebeia e seus aspectos culturais. O autor aponta para uma dimensão de resistência que se caracteriza por garantir as condições de sobrevivência dos camponeses, sem fundo ideológico ou perspectiva revolucionária. Trata-se de uma resistência que se produz, reproduz, se reinventa e se fortalece na dinâmica social das tensões cotidianas, em que o propósito é garantir a sobrevivência.

Diferente da área da estudada, a região de cerrado, localizada acima da serra do Parecis, que inclui parte do município de Tangará da Serra, iniciou o seu processo de colonização somente no final da década de 70 e início da década de 80 . Impulsionada pelo processo de maquinização da atividade agrícola, as áreas foram adquiridas por fazendeiros diretamente do Estado, constituindo hoje as fazendas do agronegócio.

Nessa região, há uma pressão muito forte do agronegócio, com um histórico de conflitos em relação à posse de terras, inclusive avançando sobre áreas indígenas, porém, apesar da relevância do assunto, não se coloca como objeto da presente reflexão.

\section{Considerações finais}

A análise proposta levou-nos a aprofundar discussões em torno do processo de ocupação das terras mato-grossenses, com foco na comunidade Córrego das Pedras, no Município de Tangará da Serra, na região sudoeste de Mato Grosso. O local teve o processo de colonização e ocupação tardia em função das especificidades de uma região que não comportava a exploração mineral, principal atividade que foi âncora para o processo de colonização e desenvolvimento do Estado.

É importante ressaltar que a explicitação do processo de ocupação das terras matogrossenses só pode ocorrer no contexto da compreensão de um cenário macro de ocupação das terras brasileiras e da modernização do campo, particularmente no centro-sul brasileiro, importante produtor dos processos migratórios.

Procuramos evidenciar a relação de um cenário nacional de ocupação do campo, talhado por privilégios às elites agrárias, determinante para um modelo com base no latifúndio e suas implicações em um Estado continental, rico em produção mineral e terras férteis propícias à prática da agricultura, pecuária e extração madeireira.

Além disso, foram apontados os efeitos da política de modernização do campo implementado no centro-sul brasileiro, e sua repercussão na ocupação do sudoeste do Estado de Mato Grosso. Tal processo foi perceptível especificamente na ocupação das terras do 
Município de Tangará da Serra, receptor da massa de camponeses expropriados das regiões mineiras, paulistas e paranaenses, locais palco do processo de modernização que produziu a migração dessa população.

Evidenciamos que a migração se transformou em um desafio, porque as famílias não tinham noção do que iriam encontrar em um local desprovido de atividade de comércio, portanto, sem o que comprar e sem mecanismos para vender suas produções, sem infraestrutura, expostos à trágicas doenças, enfim, sem às mínimas condições de sobrevivência humana. Resistiram, conquistaram a terra e nela permanecem, tendo que, ao logo do tempo, se reinventar, em função da necessidade de alteração dos mecanismos de produzir suas sobrevivências.

Por último, apontamos a trajetória de vida dos sitiantes, migrantes do centro-sul brasileiro, como uma resistência cotidiana, apontada por Scott (2002), que inicia desde o dia em que se deu a migração no início da década de 60, estendendo-se por mais de cinquenta anos, até contemporaneamente, redescobrindo meios e formas de produção, e descobrindo o caminho da feira para a comercialização. Uma constante e permanente luta pela conquista e permanência na terra, produzindo e reproduzindo vida material e imaterial, ou seja, uma experiência de vida e de relação com a terra.

\section{Referências bibliográficas}

BARROZO, João Carlos. Em busca da pedra que brilha como estrela: garimpos e garimpeiros do Alto Paraguai-Diamantino. Cuiabá: Tanta Tinta, 2007.

BARROZO, João Carlos. A questão agrária em Mato Grosso: a persistência da grande propriedade. BARROZO, João Carlos (Org.). MATO GROSSO: a (re)ocupação da terra na fronteira amazônica (século XX). Cuiabá: EdUFMT, 2010. p. 11-27.

BOSI, Ecléa. Memória e sociedade: lembrança de velhos. $3^{\text {a }}$. ed. São Paulo: SCHWARCZ, 2004.

CANDIDO, António. Os parceiros do Rio Bonito. 6a . ed. São Paulo: Duas Cidades, 1982. 
CHIAVENATTO, Julio José. Genocídio americano: a Guerra do Paraguai. $3^{\text {a }}$. ed. São Paulo: Brasiliense, 1979.

FRIEIRO, Eduardo. Feijão, angu e couve. 2 ${ }^{\text {a }}$ ed. São Paulo: Itatiaia, 1982.

GUIMARÃES NETO, Regina Beatriz. Cidades da mineração: memória e práticas culturais: Mato Grosso na primeira do metade do século XX. Cuiabá: EDUFMT, 2006.

IBGE Cidades@. Tangará da Serra. Disponível em: www.cidades.ibge.gov.br. Acesso em: 24 nov. 2106.

INSTITUTO NACIONAL DE COLONIZAÇÃO E REFORMA AGRÁRIA (INCRA). Classificação de imóveis rurais. Disponível em: http://www.incra.gov.br/tamanhopropriedades-rurais. Acesso em: 24 de abril de 2016.

LUCENA, Célia Regina Toledo. Artes de lembrar e de inventar: (re)lembranças de migrantes. São Paulo: Arte \& Cia, 1999.

MARIEN, Alfredo. Era um poaeiro. Cuiabá: Academia Matogrossense de Letras, 2008.

MARTINS, José de Souza. Os camponeses e a política no Brasil. Petrópolis: Vozes, 1986.

MOREIRA, Roberto José. Terra, poder, território. São Paulo: Expressão Popular, 2007.

MORENO, Gislaene. Terra e poder em Mato Grosso: política e mecanismos de burla/1892/1992. Cuiabá: EDUFMT, 2007.

OLIVEIRA, Ariovaldo Umbelino de. Amazônia: monopólio, expropriação e conflitos. 3. ed. Campinas: Papirus, 1990.

OLIVEIRA, Carlos Ednei de. História de Tangará da Serra. Tangará da Serra: Sanches, 2012. 
SCOTT, James C. Formas cotidianas da resistência camponesa. Tradução de Marilda A. de Menezes e Lemuel Guerra. Raízes, Campina Grande; v. 21, n. 01, p. 10-31, jan.- jun. 2002.

SCOTT, James C. Exploração normal, resistência normal. Revista Brasileira de Ciência Política. n. 5. Brasília jan/jul, 2011. Disponível em: http://www.scielo.br/scielo.php?script=sci_arttext\&pid=S0103-33522011000100009. Acesso em: 17 jan. 2019.

SILVA, Maria Aparecida de Moraes. Errantes do fim do século. São Paulo: UNESP, 1999.

THOMPSON, E. P. Costumes em Comum: estudos sobre a cultura popular e tradicional. Tradução de Rosaura Eichemberg. 1 ${ }^{\text {a }}$. ed. (9 . Reimp.) São Paulo: Schwarcz, 2016.

WOORTMANN, Ellen F; WOORTMANN, Klass. O trabalho da terra: a lógica e a simbólica da lavoura camponesa. Brasília: UNB, 1997. 